\title{
Nota sôbre Cromossômios de alguns Ortópteros do Brasil
}

\author{
S. DE TOLEDO PIZA \\ Escola Superior de Agricultura "Luiz de Queiroz" \\ Universidade de S. Paulo
}

\section{INDICE}

Pseudophyllidae

Copiphoridae

Sumary . . . . . . . . . . . . . . . . . 135

Literatura Citada 


\section{PSEUDOPHYLLIDAE}

Meroncidius intermedius Brunner. Os espermatogônios em metáfase exibem 30 autossômios de tamanhos diferentes, 14 dos quais são visivelmente maiores que os 16 restantes. (Fig. 1, A). Os maiores, conjuntamente com o sexo-cromossômio, formam um círculo, em cuja parte central se dispōem os menores. Dos autossômios maiores, 4 são indubitavelmente metacêntricos e ficam com ambos os braços dirigidos para o lado de fora do círculo. Entretanto, uma ou outra vez se encontra um dêsses autossômios com um dos braços para o centro, ou então, dobrado como de costume, porém localizado na parte central, ao lado dos pequenos.

$\mathrm{O}$ sexo-cromossômio tem a forma de $\mathrm{V}$ de ramos desiguais e embora não seja demasiado grande, é o maior elemento da placa. Na prófase êsse elemento se deixa reconhecer como um espêsso filamento heteropicnótico de forma helicoidal, disposto perifericamente, no interior de uma vesícula alongada. (Fig. $1 \mathrm{~B})$. Na anáfase os seus braços caminham distendidos atrás dos autossômios.

Os espermatócitos primários apresentam 15 tétrades autossomais, sendo 7 grandes e 8 pequenas, dispostas sem qualquer ordem. (Fig. 1, C). Na metáfase se constata que o heterocromossômio, elemento espêsso, condensado e ligeiramente recurvado, fica desorientado, em qualquer posição, numa vesícula, geralmente fora do plano equatorial. A célula parece pequena para conter os cromossômios, ficando porisso completamente tomada por êles. Menos frequentemente os autossômios se apresentam bem separados, como na Fig. 1,C; na maioria dos casos êles se aglomeram, estabelecendo contato.

Apenas um dos espermatócitos secundários recebe o sexocromossômio. Daí a existência de espermatócitos secundários com 16 e com 15 elementos. Os espermatócitos se dividem como nos casos conhecidos, dando origem a espermatídios e por conseguinte a espermatozóides com X e sem X em numeros iguais.

O macho de Meroncidius intermedius é, pois, do tipo sexual $\mathrm{X}-\mathrm{O}$.

Os Pseudophyllidae têm sido pouco estudados do ponto de vista citológico. Que me conste, é esta a quinta espécie estudada do grupo. Três das anteriormente investigadas pertencem ao gênero Jamaicana (WOOLSEY 1915) e a quarta ao gênero Sathrophyllia (ASANA, MAKINO \& NIIYAMA 1938). Essas quatro espécies concordam quanto ao número de cromossômios e à forma do heterocromossômio. Tôdas elas possuem 34 autossômios e um grande $\mathrm{X}$ acrocêntrico. 


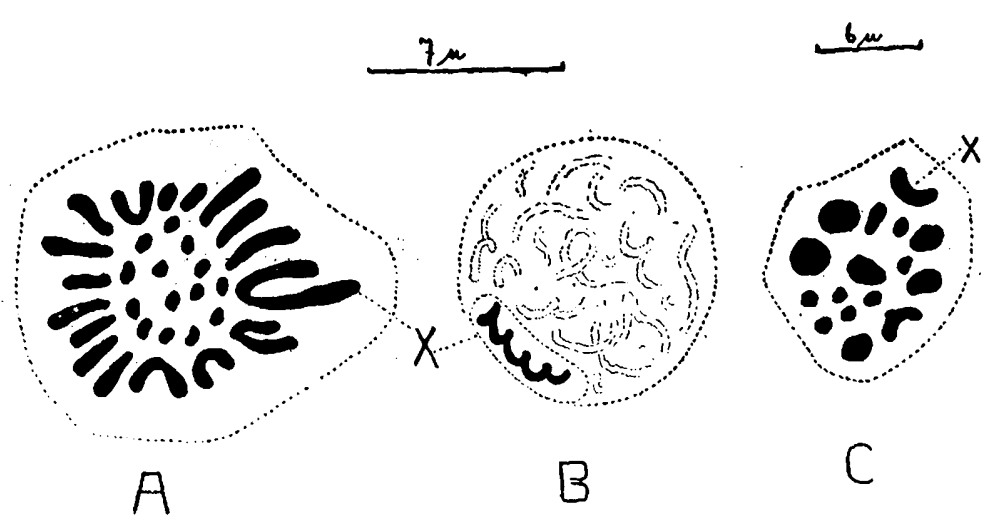

Fig. 1 - Meroncidius intermedius Brunner.

A) Metáfase espermatogonial; B) Prófase espermatogonial;

C). Metáfase primária.

A presente espécie se destaca por possuir apenas 30 autossômios e um sexo-cromossômio inquestionavelmente metacêntrico. E' provável que Meroncidius intermedius tenha evoluido de uma espécie provida, como as precedentes, de 34 autossômios acrocêntricos, pela fusão, dois a dois, de alguns dêsses elementos. Assim, se considerarmos os quatro autossômios em formá de $\mathrm{V}$ como tendo resultado da fusão pela extremidade cêntrica' de autossômios primitivamente acrocêntricos, cada um dêles, por conseguinte, representando dois dos primitivos cromossômios, teremos, exatamente, 34 elementos. Aliás, redução do número de autossômios para 33 e para 32, com a correspondente presença de cromossômios metacêntricos, assinalada por WOOLSEY em Jamaicana subguttata e Jamaicana unicolor, foi atribuida àquele processo de fusão. Transformação de cromossômios acrocêntricos em cromossômios metacêntricos, com a consequente redução numérica, tem sido observada em Ortópteros pertencentes a diversas outras Famílias. (Ref. em WHITE 1945).

Quanto à origem da metacentricidade do sexo-crómossômio de Meroncidius, nada posso dizer por enquanto. 


\section{COPIPHORIDAE}

Oxyprora flavicornis Redt. Espermatogônios com 29 cromossômios, isto é, com 28 autossômios e um heterocromossômio. (Fig. 2, A). Como de costume, os autossômios menores ficam no centro e os maiores na periferia. Dos maiores, 4, embora curtos e grossos, mostram-se ligeiramente recurvados, com a convexidade geralmente voltada para o centro, parecendo tratar-se de elementos metacêntricos. $O$ heterocromossômio, bastante espêsso, tem a forma de um $\mathrm{V}$ de ramos quase iguais.

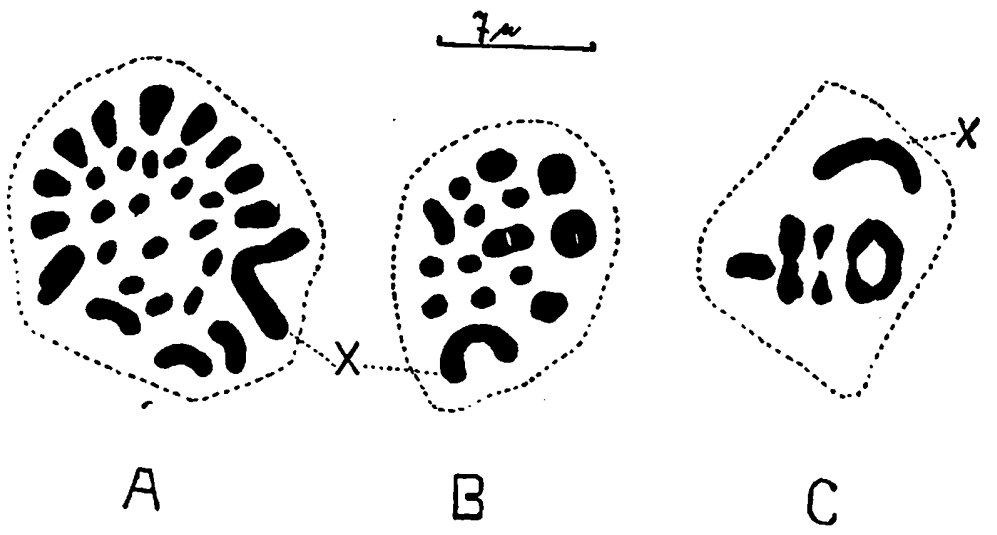

Fig. 2 - Oxyprora flavicornis Redtb.

A) Metáfase espermatogonial; B) Vista polar da metáfase primária; C) Vista lateral da metáfase primária.

Os espermatócitos primários exibem 14 tétrades autossomais e o sexo-cromossômio que costuma ficar fora do plano equatorial. (Fig. 2, B). Nas vistas laterais se constata que o cromosŝtmio $X$ apresenta na parte convexa uma incisão correspondente ao ponto de inserção. (Fig. $2, \mathrm{C}$ ). $\mathrm{Na}$ anáfase verifica-se que há, realmente, pelo menos, dois pares de autossômios metacêntricos. 
Neoconocephalus infuscatus (Scudd.). Nesta espécie pude apenas constatar que o heterocromossômio é metacêntrico e que cs espermatócitos secundários são providos de 14 cromossômios $(13 \mathrm{~A}+\mathrm{X})$ e de 13. Verifiquei igualmente que as placas metafásicas dos espermatogônios, que devem possuir 27 cromossômios, exibem um elevado número de elementos metacêntricos, os quais, a avaliar pelas metáfases secundárias, são, no mínimo, em número de 8 (4 pares).

Do gênero Neoconocephalus só conheço referência a uma espécie não determinada, do Mexico, com 22 auıossômios, 8 dos quais metacêntricos e um heterocromossômio igualmente metacêntrico. (WHITE 1941 e 1945).

Se admitimos que um mecanismo de fusão cêntrica está operando na Família, para reduzir o número de cromossômios de suas espécies, devemos esperar encontrar as espécies originárias com 31, 33 e 35 cromossômios, sendo acrocêntricos todos os autossômios.

\section{SUMMARY}

A short. report on the chromosomes of three species of Brasilian Orthoptera is given in the present paper.

Meroncidius intermedius Brunner, belonging to the Pseudophyllidae, differs from the species already studied in the Family in having 30 instead of 34 autosomes and a metacentric sex chromosome. Of the autosomes, 4 showed to be metacentric. The author believes that the present species may be originated from one having 34 acrocentric autosomes by means of centric fusions. The origin of th 2 metacentricity of the $X$ is not discussed.

Oxyprora flavicornis Redtb.,belonging to the Copiphoridae, has spermatogonia with 29 chromosomes. Of the autosomes, 4 seemed to be metacentric. The $X$ has the form of a $V$ of subaequal arms.

Neoconocephalus infuscatus (Scudd.), also belonging to the Copiphoridae, is provided with secondary spermatocytes of $13+\mathrm{X}$ and 13 chromosomes. The heterochromosome is metacentric. In the spermatogonia, whose chromosome number has not been counted, there are a lot of metacentric elements. In the opinion of the present writer species provided with 31, 33 and 35 chromosomes should exist in the Copiphoridae. 


\section{LITERATURA CITADA}

ASANA, J. J., S. MAKINO \& H. NIIYAMA, 1938 - A chromosomal survey of some Indian insects. I - Morphology of the chromosomes in eight species of the Locustidae. J. of the Fac. of Sc. Hokkaido Imp. Uni. Ser. IV, Zoology, 4 (3): 211-234.

WHITE, M. J. D., 1941 - The evolution of the sex chromosomes. II The X-chromosome in the Tettigonidae and Acrididae and the principle of "Evolutionary Isolation" of the X. J. of Genetics, 42 (1-2): 173-190.

WHITE, M. J. D., 1945 - Animal cytology and evolution. Cambridge Univ. Press. VIII-375 pgs.

WOOLSEY, C., 1915 - Linkage of chromosomes correlated with reduction in numbers among the species in a genus, also within a species of the Locustidae. Biol Bul. 28 : 163-187. 